\title{
Measuring of Islamic Business Ethics in Indonesia Islamic Bank
}

\author{
Sopyan Saori \\ Department of Business Administration, \\ Universitas Padjadjaran, \\ Bandung, Indonesia \\ Bambang Hermanto \\ Department of Business Administration, \\ Universitas Padjadjaran, \\ Bandung, Indonesia \\ Iwan Sukoco \\ Department of Business Administration, \\ Universitas Padjadjaran, \\ Bandung, Indonesia
}

\begin{abstract}
The business characteristic of Islamic banks is the implementation of Islamic business ethics. Parallel with the trend of increasing preference to ethical institution, Islamic banks should put this as its competitive edge toward its competitor conventional competitor banks. However, only few previous studies discussed about the implementation of Islamic business ethics within Islamic banks and none suggested how to measure such implementation. This paper is a study of the literature on ethics and used descriptive qualitative methods as data analytical. The unit of analysis in this study is employees of Islamic Bank in Indonesia. This paper synthesizes the dimensions of Islamic business ethics extracted from the Quran and Sunnah, which were proposed by previous research and divided into five dimensions there are, the union of unity, balance, free will, responsibility and truth. Furthermore, this paper describes the findings through deep interviews with information. Opportunities for future empirical studies are recommended at the end of this paper.
\end{abstract}

Keywords: Islamic business ethics, Islamic banking

\section{INTRODUCTION}

Generally, most of banking in Indonesia are conventional bank. The phenomenon that occurred when the monetary crisis in Indonesia in 1998 caused national economic chaos, conventional banking that referred to the international economic system could not survive and collapse. At that time, the first Islamic bank to be established was Muamalat bank which could survive even though profit fell. Bank Muamalat, which basically uses the principle of profit sharing, survived the crisis because of its variety of products, such as profit sharing financing products that were not affected by Bank Indonesia Central interest rate fluctuations, so the real sector using these funds also survived the crisis (Syafi \& Antonio, 2001).

The business of banking is about integrity, because banks manage the depositors' funds and lend those funds to debtors responsibly (Lewison, 1999). Therefore, ethical conduct of doing business is crucial to maintain trust of customers to the banks' integrity. Each bank usually set code of conduct as the guidance of implementation of ethics. 
The issue of ethics in the Islamic bank is even more crucial. As modern bank institutions, Islamic banks should operate strictly in compliance with Islamic law (sharia) based on the Quran and Sunnah (Koku \& Savas, 2014). Islamic banks are usually described themselves as being providers of ethical financial services (Amin, Abdul-Rahman, \& Razak, 2014). Parallel with the trend of increasing preference to ethical institution (Widana, Wiryono, Purwanegara, \& Toha, 2014), Islamic banking should take benefit of this condition for boasting their further growth (Widana et al., 2014).

Badroen et al. (2007) also expressed his opinion that Ethics is a discussion of good, bad, should, right, and wrong. The most prominent thing is about (good) and the theory of obligations, both of which are related to conscience and take shelter under moral philosophy. Terminologically Badroen et al. (2007) reveals the word ethics is very close to the term of AlQur'an al-khuluq. To describe the concept of virtue, the Al-Qur'an uses several terms, such as khair, bir, qist, 'adl, haqq, ma'ruf, dan taqwa.

According to Islamic teaching, business cannot be conducted in a way in which one become a loser nor greedy(Al-Nashmi \& Almamary, 2017), ensure a balance between profits of companies and the obligation to deliver safe and quality products for customer and towards benefit of social welfare (Koku \& Jusoh, 2014). It guides to accomplish value-maximization for the wider welfare of the society on the ground of equity and justice (comprising fair play and just dealing) (Sidani \& Al Ariss, 2015). Indeed, Islamic finance scholars argued that the last global financial crisis in 2008 is a crisis, because of failed morality, greed, exploitation and corruption (Koehler, 2011). It was the result of a system of economic without divine ethical spirit in its practices (Adebayo \& Hassan, 2013), thereby the main aim of organization is based only on expansionary motive particularly profitability and growth (Badruldin et al., 2012)

Based on the systematic mapping study as literature review in this paper, Islamic business ethics is divided into general provisions (basic axioms) as stated by Badroen et al. (2007) as follows, there are unity, equilibrium, free will, responsibility, benevolence.

The concept unity means that Allah as the Almighty God sets certain limits on human behavior as a caliph, to provide benefits to individuals without sacrificing the rights of other individuals Badroen et al. (2007) also explains the social, political, religious, moral, and legal principles that bind the community and their institutional devices in such a way that an integrated system unit directs each individual human being so that they can properly implement, control and supervise, these rules.

The understanding of equilibrium in Islam is directed so that the rights of others, the rights of the social environment, the rights of the universe, and the rights of Allah and the Messenger are valid as stakeholders of one's fair behavior. All these rights must be placed properly (according to sharia rules).

According to Badroen et al. (2007) free will is directed to the good of every interest for the entire Islamic community, both in the agricultural, industrial, trade and other sectors. The prohibition on the form of monopoly, fraud and usury practices is a guarantee of the creation of a healthy market mechanism. One of the peculiarities and advantages of the Islamic economic ethics system is its unity with moral and spiritual values. Without moral control, the tendency to strengthen consumerism, for example, will arise the practice of usury, monopoly, and fraud will become a tradition. 
Responsibility, it means the attitude of applying good conducts due to the sense of having to appear before God and to account for one's actions (Ibrahim \& Mahmood, 2016). The dimension of responsibility is the consequences of "free will" which is given by God to human (as His vicegerents) to exploit the word for the shake of social benefit (Widana et al., 2014), without responsibility, human equipped with free will can harm oneself, society and environment (Badroen et al., 2007). The implementation of responsibility, Saidi, 2009 as well as (Amin et al., 2014) talked about prohibition of vanity (gharar) refers to asymmetric information, which an exchange contracts may become unclear to the parties.

Benevolence It means as behavior which gives benefits to other persons with fineness and manumit (Ali, Al-Aali, \& Al-Owaihan, 2013) and contrasts with self-interest principle as implied in contemporary economics (Karakas, Sarigollu, \& Kavas, 2015). It projects goodness and generosity, encompasses mercy, justice, forgiveness, tolerance and attentiveness (Ali et al., 2013). As result, the implementation, of the principle of benevolence will treat relationships and interaction with others as primarily personal, non-discriminatory (Ali et al., 2013), and beneficial beyond self and immediate interests and avoid behaving at the expense of others for the sake of maximizing his own benefit (Karakas et al., 2015). The other implementation particularly in banking, benevolence is need when a debtor cannot pay due loan because facing difficulty, bank will be lenient (Badruldin et al., 2012).

\section{RESEARCH METHODS}

This research is qualitative in that the data is obtained by conducting interviews directly with the parties concerned, then the interpretation of the findings (deep-interview) in the field is associated with theories relating to the Principles of Islamic Business Ethics. The result of this research is the Islamic Business Ethics Framework in the Sharia Banking Industry, with Research Locus at the PT BRI Syariah Sukabumi. Islamic Business Ethics will become a reference for the company's management strategy in the perspective of the organization or human resources, to create a competitive advantage in the future.

Scientific research is a study that requires scientific procedures so that the conclusions obtained are truly objective and precise. To test the validity of the data obtained to measure the validity of the results of this study, it was done by increasing perseverance in research, they are making more careful, careful and continuous observations using triangulation techniques. The triangulation referred to in this study is source triangulation, namely comparing data obtained through time and different tools or techniques, by comparing the results of observations with interview data, then comparing the results of interviews with documentation data.

Then, the initial data to the final data are expected to be more sustainable and in accordance with the facts in the field. Finally, in making conclusions the results of this thesis research are more systematic and targeted as of the data described in the text is in accordance with the actual reality.

\section{RESULTS AND DISCUSSION}

The business activities are classified into three aspects, there are raising funds (funding), aspects of channeling funds (loans) and aspects of other banking services. The application of the concept of Islamic business ethics to the management of PT. Bank BRI Syariah Sukabumi Branch is approved in the following activities, which are approved: 


\section{Unity}

The results of research conducted in the field indicate that PT. Bank BRI Syariah Sukabumi Branch has implemented unity ethics on the corporate system. This can be seen from the resting time during prayer times which shows that PT. Bank BRI Syariah Sukabumi Branch still manages to unite Allah above everything. Besides that, PT. Bank BRI Syariah Sukabumi Branch also provides net benefits for social activities and is given to people who are entitled to. The aspect of unity which includes commitment in the initial prayer time in congregation which in its implementation has not been able to be carried out thoroughly by the employees because the instructions which are only appeals are not the standard rules and limitations of the prayer room used. Besides that, the management of alms is routinely carried out but in the aspect of zakat it is not collectively coordinated.

\section{Equilibrium}

The aspect of equilibrium which includes fairness in service to both consumers and employees, openness to healthy competition and establishing good relationships between employees and consumers. From the results of research with interview methods, researchers used three basic points as a concept of justice, among others, corporate justice both to employees and customers as well as openness to suggestions and criticism of employee negligence in providing services and to fair competition against other Islamic banks.

\section{Free Will}

In its service based on Islamic business ethics, PT. The BRI Syariah Bank Sukabumi Branch especially for non-Muslim customers to be given an explanation in the products offered is general in nature but still refers to Islamic business ethics itself. The employees are very tolerant of non-Muslim customers in choosing PT. Bank BRI Syariah Sukabumi Branch because in its activities the employees do not discriminate between various ethnic groups, religions, races and so on. This is stated in one of the hadiths which state that Allah blessed someone who was friendly and tolerant in doing business (H.R. Bukhari and Tarmidzi).

PT. The Bank BRI Syariah Sukabumi Branch also makes the concept of freedom in doing business, especially in terms of development or innovation so that business can run straight in accordance with the principles of Islamic business ethics itself.

\section{Responsibility}

To fulfill the demands of unity and justice, PT. Bank BRI Syariah Sukabumi Branch is willing to take responsibility for each action with its compliance with the rules or standards set by Bank Indonesia, the Sharia Supervisory Board (DPS) BRI and the fatwa directives of the National Sharia Council (DSN) MUI (Indonesian Ulama Council). The principle of responsibility is closely related to the principle of monotheism, balance and free will. All obligations need to be respected unless they are morally wrong. A person cannot blame someone for his own actions, but he must bear the highest responsibility for his own actions (Djakfar: 2014). The application of ethics of responsibility is also carried out by the company by making company certification to be incorporated. Companies that have been certified or have legal entities show that the company is serious about establishing a company as an effort to take responsibility to consumers. Because running a business that is preferred is the convenience of consumers by serving them well and responsibly.

\section{Benevolence}

behavior is recommended in Islam because the Qur'an and the Prophet always emphasize honesty in business. The Messenger of Allah not only said through his hadiths, but also gave a direct example of how to trade honestly by describing the actual merchandise without any 
element of lies when explaining the type, type, source and cost. As explained in one of the hadith narrated by Imam Muslim which reads, as the Messenger of Allah who always appealed for the price of an item to be adjusted to the values contained in it. In addition, pricing must be adjusted to prices that apply in the market and in accordance with the prevailing habits in a region. With a low price, it will not necessarily reduce income, because consumers will buy more often when the price of a product is cheaper than what consumers think.

Based on the results of the discussion above, the researcher draws conclusions as what the existing conditions are based on the basic principles of Islamic business ethics at PT. In general, the BRI Syariah Bank Sukabumi Branch has been implemented even though it has not been maximal especially in terms of managing Human Resources (HR). Whereas in its implementation, all staff of PT. Bank BRI Syariah Sukabumi Branch has implemented even though in particular the application of the monotheistic ethics of Islamic business is not optimal. Although the application is not maximal, with spiritual intelligence possessed, but at least the staff of PT. Bank BRI Syariah Sukabumi Branch will feel peace of mind and every behavior will be maintained from things that deviate from the teachings of Islam and continue to try to fix the most important things in the concept of tauhid in Islamic business ethics which is considered lacking.

\section{CONCLUSION}

Based on the results of the study, the existing conditions at PT. Bank BRI Syariah Sukabumi Branch which consists of policies, Standard Operating Procedures (SOP), management of Human Resources (HR), and Facilities already based on the principles of Islamic business ethics even though the aspects of HR management of PT. Bank BRI Syariah has not implemented training for employees based on understanding Islamic business ethics so that it has an impact on the application of Islamic business ethics itself.

PT. Bank BRI Syariah Sukabumi Branch needs to pay attention to every activity in its business practices and develop business strategies using the Islamic Business Ethics approach and Islamic banking practices. PT. Bank BRI Syariah Sukabumi Branch must further improve the quality of Human Resources to ensure customer service that impacts on customer trust.

For employees of PT. Bank BRI Syariah Sukabumi Branch, to improve the capabilities of human resources in the form of knowledge of Islamic principles, so that the identity of PT. Bank BRI Syariah Sukabumi Branch as a Sharia-based company gets a better image in the eyes of customers.

For academics, based on theoretical aspects this research is expected to be a reference for the science of developing Islamic Business Ethics, and to examine more deeply the Islamic principles of Islamic companies so that they can become scientific justifications for other studies in the future.

For further research, it is expected not only to focus on the Principles of Islamic Business Ethics at the level of human resources, but they also focus on another principle, such as Islamic business ethics at the level of Islamic products and business activities of banking companies. In addition, further research is needed on the application of Islamic business ethics to other types of companies, so that it can be seen whether research in other companies can also use Islamic business ethics principles that are applied to Islamic Banking or not. 


\section{Reference}

Al-Nashmi, M. M., \& Almamary, A. A. (2017). The relationship between Islamic marketing ethics and brand credibility: A case of pharmaceutical industry in Yemen. Journal of Islamic Marketing, 8(2), 261-288. https://doi.org/10.1108/JIMA-03-2015-0024

Ali, A. J., Al-Aali, A., \& Al-Owaihan, A. (2013). Islamic Perspectives on Profit Maximization. Journal of Business Ethics, 117(3), 467-475. https://doi.org/10.1007/s10551-012-1530-0

Amin, H., Abdul-Rahman, A.-R., \& Razak, D. A. (2014). Theory of Islamic consumer behaviour: An empirical study of consumer behaviour of Islamic mortgage in Malaysia. Journal of Islamic Marketing, 5(2), 273-301. https://doi.org/10.1108/JIMA-06-2013-0042

Badroen, F., Suhendra, Mufraeni, M. A., \& Bashori, A. D. (2007). Etika Bisnis Dalam Islam. Kencana Prenada Media Group.

Badruldin, B., Mohamed, Z., Sharifuddin, J., Rezai, G., Abdullah, A. M., Latif, I. A., \& Mohayidin, M. G. (2012). Clients' perception towards JAKIM service quality in Halal certification. Journal of Islamic Marketing, 3(1), 59-71. https://doi.org/10.1108/17590831211206590

Ibrahim, N. M. N., \& Mahmood, R. (2016). Mediating role of competitive advantage on the relationship between entrepreneurial orientation and the performance of small and medium enterprises. International Business Management.

Karakas, F., Sarigollu, E., \& Kavas, M. (2015). Discourses of Collective Spirituality and Turkish Islamic Ethics: An Inquiry into Transcendence, Connectedness, and Virtuousness in Anatolian Tigers. Journal of Business Ethics, 129(4), 811-822. https://doi.org/10.1007/s10551-014-2135-6

Koehler, B. (2011). The economist mohammed ibn abdullah (570-632). Economic Affairs, 31(1), 109-111. https://doi.org/10.1111/j.1468-0270.2010.02060.x

Koku, P. S., \& Jusoh, O. (2014). Where do we go from here? Towards a theory in Islamic marketing. Journal of Islamic Marketing, 5(3), 366-378. https://doi.org/10.1108/JIMA-03-2013-0022

Koku, P. S., \& Savas, S. (2014). On corporate social responsibility and Islamic marketing. Journal of Islamic Marketing, 5(1), 33-48. https://doi.org/10.1108/JIMA-04-2013-0028

Lewison, M. (1999). Conflicts of interest? The ethics of usury. Journal of Business Ethics, 22(4), 327-339. https://doi.org/10.1023/A:1006164904326

Sidani, Y., \& Al Ariss, A. (2015). New Conceptual Foundations for Islamic Business Ethics: The Contributions of Abu-Hamid Al-Ghazali. Journal of Business Ethics, 129(4), 847-857. https://doi.org/10.1007/s10551-014-2136-5

Syafi, M., \& Antonio. (2001). BAB IV PROFIL PERUSAHAAN 4.1 Sejarah Bank Muamalat Indonesia (BMI). Jakarta:Gema Insani.

Widana, G. N. O., Wiryono, S. K., Purwanegara, M. S., \& Toha, M. (2014). Measuring Islamic business ethics within Indonesia Islamic banks. Global Journal Al-Thaqafah, 4(2), 5-15. Retrieved from https://www.scopus.com/inward/record.uri?eid=2-s2.0-

84920940670\&partnerID=40\&md5=d70 eee40a7e4b6bc663423cb95ad3ace 